\title{
Continuous multi-component MAX-DOAS observations for the planetary boundary layer ozone variation analysis at Chiba and Tsukuba, Japan, from 2013 to 2019
}

Hitoshi Irie ${ }^{1 *}$ D, Daichi Yonekawa ${ }^{1}$, Alessandro Damiani ${ }^{1}$, Hossain Mohammed Syedul Hoque ${ }^{1,2}$, Kengo Sudo $^{2}$ and Syuichi Itahashi ${ }^{3}$

\begin{abstract}
Ground-based remote sensing using multi-axis differential optical absorption spectroscopy (MAX-DOAS) was used to conduct continuous simultaneous observations of ozone $\left(\mathrm{O}_{3}\right)$, nitrogen dioxide $\left(\mathrm{NO}_{2}\right)$, and formaldehyde $(\mathrm{HCHO})$ concentrations at Chiba (35.63 $\mathrm{N}, 140.10^{\circ} \mathrm{E}, 21 \mathrm{~m}$ a.s.l.) and Tsukuba ( $36.06^{\circ} \mathrm{N}, 140.13^{\circ} \mathrm{E}, 35 \mathrm{~m}$ a.s.l.), Japan, for 7 years from 2013 to 2019. These are urban and suburban sites, respectively, in the greater Tokyo metropolitan area. $\mathrm{NO}_{2}$ and $\mathrm{HCHO}$ are considered to be proxies for nitrogen oxides (NOx) and volatile organic compounds (VOCs), respectively, both of which are major precursors of tropospheric $\mathrm{O}_{3}$. The mean concentrations below an altitude of $1 \mathrm{~km}$ were analyzed as planetary boundary layer (PBL) concentrations. For a more spatially representative analysis around the urban area of Chiba, four MAX-DOAS instruments directed at four different azimuth directions (north, east, west, and south) were operated simultaneously and their data were unified. During the 7-year period, the satellite observations indicated an abrupt decrease in the tropospheric $\mathrm{NO}_{2}$ concentration over East Asia, including China. This suggested that the transboundary transport of $\mathrm{O}_{3}$ originating from the Asian continent was likely suppressed or almost unchanged during the period. Over this time period, the MAX-DOAS observations revealed the presence of almost-constant annual variations in the PBL $\mathrm{O}_{3}$ concentration, whereas reductions in $\mathrm{NO}_{2}$ and $\mathrm{HCHO}$ concentrations occurred at rates of approximately 6-10\%/year at Chiba. These changes provided clear observational evidence that a decreasing NOx concentration significantly reduced the amount of $\mathrm{O}_{3}$ quenched through NO titration under VOC-limited conditions in the urban area. Under the dominant VOC-limited conditions, the MAX-DOAS-derived concentration ratio of $\mathrm{HCHO} / \mathrm{NO}_{2}$ was found to be below unity in all months. Thus, the multi-component observations from MAX-DOAS provided a unique data set of $\mathrm{O}_{3}, \mathrm{NO}_{2}$, and $\mathrm{HCHO}$ concentrations for analyzing $\mathrm{PBL} \mathrm{O}_{3}$ variations.
\end{abstract}

Keywords: Ground-based remote sensing, MAX-DOAS, multi-component observation, PBL, tropospheric ozone chemistry, nitrogen dioxide, formaldehyde

\footnotetext{
* Correspondence: hitoshi.irie@chiba-u.jp

${ }^{1}$ Center for Environmental Remote Sensing, Chiba University, 1-33 Yayoicho,

Inage-ku, Chiba 263-8522, Japan

Full list of author information is available at the end of the article
}

\section{Springer Open}

(c) The Author(s). 2021 Open Access This article is licensed under a Creative Commons Attribution 4.0 International License, which permits use, sharing, adaptation, distribution and reproduction in any medium or format, as long as you give appropriate credit to the original author(s) and the source, provide a link to the Creative Commons licence, and indicate if changes were made. The images or other third party material in this article are included in the article's Creative Commons licence, unless indicated otherwise in a credit line to the material. If material is not included in the article's Creative Commons licence and your intended use is not permitted by statutory regulation or exceeds the permitted use, you will need to obtain permission directly from the copyright holder. To view a copy of this licence, visit http://creativecommons.org/licenses/by/4.0/. 


\section{Introduction}

Ozone $\left(\mathrm{O}_{3}\right)$ plays a critical role in the troposphere not only as a photochemical oxidant with harmful impacts on human health but also as the third most important greenhouse gas. In recent years, its importance has been more widely recognized as one of short-lived climate forcers (SLCFs) or short-lived climate pollutants (SLCPs). The SLCPs contribute to the man-made global greenhouse effect in addition to carbon dioxide. Despite its importance, recent concentration trends in Japan have indicated the existence of a paradox (Akimoto 2017), in which the concentration of surface $\mathrm{O}_{3}$ has increased despite a decrease in the concentrations of its major precursors, namely nitrogen oxides $(\mathrm{NOx} \equiv$ nitric oxide $[\mathrm{NO}]+$ nitrogen dioxide $\left.\left[\mathrm{NO}_{2}\right]\right)$ and volatile organic compounds (VOCs). After 2000, emission control measures for diesel-powered trucks in Japan were tightened significantly, resulting in an apparent decrease in ambient $\mathrm{NO}_{2}$ concentrations (e.g., Akimoto 2017). New emission control measures for VOCs from fixed sources were introduced in 2006, which further decreased ambient VOC concentrations. Nevertheless, an increase in average ambient concentrations of oxidants (Ox, a collective term, of which the major components are $\mathrm{O}_{3}$, peroxy acetyl nitrate, hydrogen peroxide, and organic hydroperoxides) was observed in the 2000s. As argued by Akimoto (2017), the paradox should reflect the following three factors: (1) a decrease in the NO titration effect, (2) an increase in transboundary transport, and (3) a decrease in in situ photochemical production of $\mathrm{O}_{3}$. Meanwhile, for China, Li et al. (2019) estimated that anthropogenic NOx emissions decreased by $21 \%$ from 2013 to 2017 and there was little change in VOC emissions. Under such conditions, an analysis of observation data from $~ 1000$ sites in China showed a slight increasing trend in ambient $\mathrm{O}_{3}$ concentrations of 1-3 ppbv/ year in the megacity clusters of eastern China only and a decreasing trend in the southern parts of China ( $\mathrm{Li}$ et al. 2019). It has been suggested that $\mathrm{O}_{3}$ production could have been stimulated by a reduction in the aerosol sink of hydroperoxy radicals due to the rapid decrease in the amount of atmospheric aerosol in China in recent years. Thus, causes of recent trends in near-surface $\mathrm{O}_{3}$ concentration and its major precursors and the relationships among them remain under discussion. Although satellite-based column density measurements have been used to derive the formaldehyde ( $\mathrm{HCHO})$ to $\mathrm{NO}_{2}$ concentration ratio as an indicator of near-surface $\mathrm{O}_{3}$ sensitivity (e.g., Martin et al. 2004), the column-based ratio was suggested to derive a different $\mathrm{O}_{3}$ sensitivity from that derived from in situ data because of the vertical gradient of the ratio (Schroeder et al. 2017). A determination of the causes leading to the $\mathrm{O}_{3}$ trend would improve our quantitative understanding of the processes leading to the variation in $\mathrm{O}_{3}$ concentrations and hence, the development of a SLCP co-control policy.

In this study, we utilized ground-based remote sensing using multi-axis differential optical absorption spectroscopy (MAX-DOAS). Continuous simultaneous observations of planetary boundary layer (PBL) $\mathrm{O}_{3}, \mathrm{NO}_{2}$, and $\mathrm{HCHO}$ concentrations in the $0-1 \mathrm{~km}$ layer (i.e., neither the tropospheric column nor the surface concentration) at Chiba $\left(35.63^{\circ} \mathrm{N}, 140.10^{\circ} \mathrm{E}, 21 \mathrm{~m}\right.$ a.s.l.) and Tsukuba $\left(36.06^{\circ} \mathrm{N}, 140.13^{\circ} \mathrm{E}, 35 \mathrm{~m}\right.$ a.s.l.), Japan (Fig. 1), were conducted by MAX-DOAS for 7 years from 2013 to 2019. Chiba and Tsukuba are located in an urban and suburban area, respectively (Fig. 1). At Chiba, four different-azimuth-viewing MAX-DOAS instruments were used to increase the spatial representativity of observations. $\mathrm{NO}_{2}$ and $\mathrm{HCHO}$ are considered proxies for NOx and VOCs, respectively. The seasonal variations and annual trends in $\mathrm{O}_{3}, \mathrm{NO}_{2}$, and $\mathrm{HCHO}$ concentrations retrieved from MAX-DOAS observations were investigated over the 7-year study period. We investigated how much of the $\mathrm{HCHO} / \mathrm{NO}_{2}$ concentration ratio could be reflected by MAX-DOAS observations under $\mathrm{O}_{3}$ sensitivity regimes, which were suggested from both the literature (e.g., Akimoto, 2017) and our study.

\section{Methods}

Continuous ground-based observations using our MAXDOAS system (e.g., Irie et al. 2008, 2011, 2015, 2019), which has participated in both the Cabauw Intercomparison Campaign of Nitrogen Dioxide measuring Instruments (CINDI) (Roscoe et al. 2010) and CINDI-2 (Kreher et al. 2020), were conducted at Chiba University, Chiba, and the Meteorological Research Institute, Tsukuba, Japan (Fig. 1), for 7 years from 2013 to 2019. The MAX-DOAS method is based on the well-established DOAS technique, which quantitatively detects narrow band absorption by trace gases by applying the LambertBeer law (e.g., Platt and Stutz, 2008). After the pioneering studies conducted by Hönninger and Platt (2002), Wittrock et al. (2004), and Hönninger et al. (2004), various instruments and algorithms for MAX-DOAS have been developed worldwide. The MAX-DOAS system used in this study employed the Maya2000Pro spectrometer (Ocean Insight, Inc., Orlando, FL, USA) (with a slit of $25 \mu \mathrm{m}$ ). It was embedded in a temperature-controlled box to record high-resolution spectra from 310 to 515 $\mathrm{nm}$ (with the full width at half maximum of approximately $0.3-0.4 \mathrm{~nm}$ and an oversampling factor of 3-4). At both Chiba and Tsukuba, measurements were conducted at five $\left(2^{\circ}, 3^{\circ}, 4^{\circ}, 6^{\circ}\right.$, and $\left.8^{\circ}\right)$ and three off-axis elevation angles $\left(2^{\circ}, 4^{\circ}\right.$, and $\left.8^{\circ}\right)$, respectively, and at the single reference elevation angle, for which $70^{\circ}$ was adopted instead of $90^{\circ}$ to reduce the variation in signals measured at all elevation angles, while the integration 


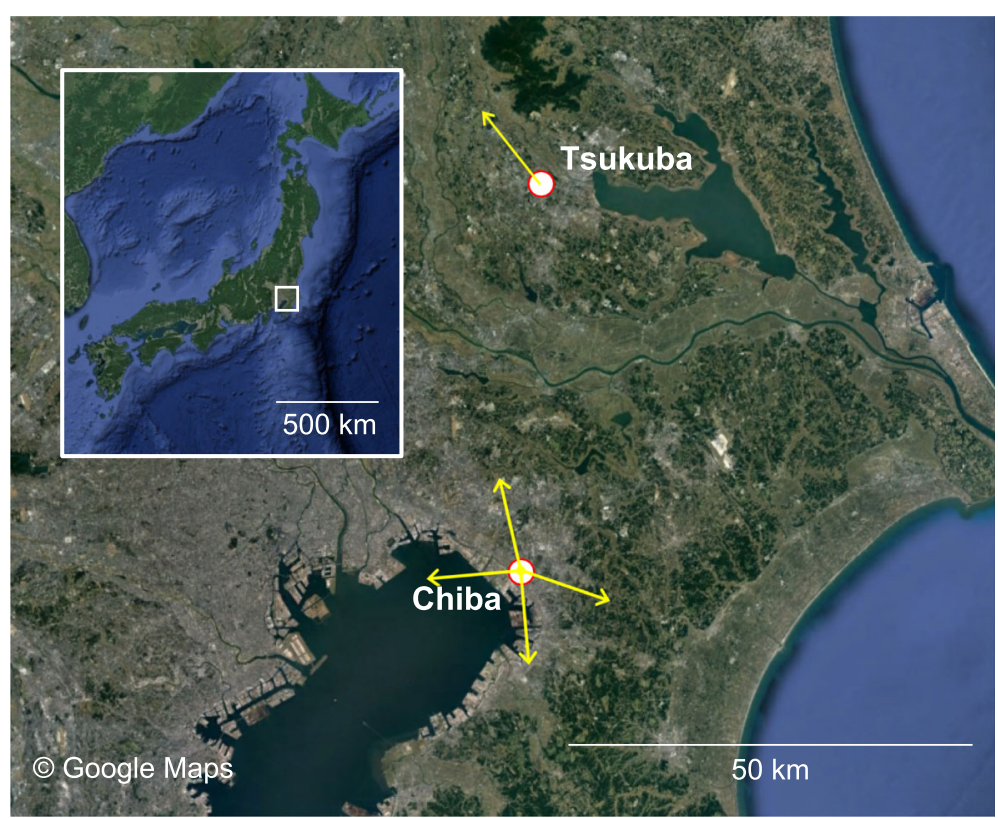

Fig. 1 Locations of the MAX-DOAS observation sites in this study (Chiba and Tsukuba, Japan). The lines with arrows represent the lines of sight for each MAX-DOAS instrument. The length of the lines represents a typical observation spatial scale of $10 \mathrm{~km}$

time was kept constant. At Chiba, we operated four MAX-DOAS instruments simultaneously, which were directed at different azimuth directions, namely north $\left(2^{\circ} \mathrm{E}\right.$ until May 16,$2014 ; 13^{\circ} \mathrm{W}$ afterwards), west $\left(7^{\circ} \mathrm{W}\right.$ until December 4, 2013; $100^{\circ} \mathrm{W}$ until May 15, 2014; $95^{\circ}$ $\mathrm{W}$ afterwards), east $\left(109^{\circ} \mathrm{E}\right.$ until May 21,$2015 ; 118^{\circ} \mathrm{E}$ afterwards), and south $\left(175^{\circ} \mathrm{E}\right.$ throughout the study period). To increase the spatial representativity around Chiba, which was situated in an urban environment, the averages of data retrieved for the four different azimuth directions were used in the analysis described below. To derive concentrations, we used the Japanese MAXDOAS profile retrieval algorithm, version 2 (JM2) (e.g., Irie et al. 2008, 2011, 2015, 2019). A daily wavelength calibration was performed using a high-resolution solar spectrum to take the possible long-term degradation of the spectrometer into consideration. A spectral fitting analysis based on the DOAS technique (Platt and Stutz 2008) was performed using the nonlinear least-squares method, and vertical profiles were subsequently retrieved using the optimal estimation method, allowing us to retrieve lower-tropospheric vertical profile information for eight quantities, including $\mathrm{NO}_{2}, \mathrm{HCHO}, \mathrm{O}_{3}$, and $\mathrm{H}_{2} \mathrm{O}$ concentrations, which were analyzed as described below. The fitting windows and absorption cross-section data used in this study were identical to those used by Irie et al. (2011, 2015). In the retrieval process, off-axis elevation angles were limited to below $10^{\circ}$ to minimize the potential systematic error in oxygen collision complex fitting results (Irie et al. 2015). This enhanced the capability for observing the PBL as a result of the loss of sensitivity to extinction at high altitudes, where clouds are usually more dominant than aerosols. Our MAXDOAS system was therefore optimized for retrieving aerosol and trace gas information in the PBL rather than across the entire tropospheric column. For the retrieval of $\mathrm{O}_{3}$, only data at a solar zenith angle (SZA) smaller than $50^{\circ}$ were analyzed, because the contribution of upper-troposphere/lower-stratosphere $\mathrm{O}_{3}$ to differential slant column densities was significant even at elevation angles smaller than $10^{\circ}$ (Irie et al. 2011). This limited MAX-DOAS $\mathrm{O}_{3}$ data to the March-October period in this study. To consider such high-altitude contributions explicitly, the state vector included the factor $f_{\text {clm }}$, with which the US standard atmosphere $\mathrm{O}_{3}$ profile above 5 $\mathrm{km}$, given as the a priori, was allowed to scale (Irie et al. 2011). In the vertical profile retrieval, the elevation angle setting was fully considered in the calculation of differential air mass factors (e.g., Irie et al. 2011, 2015). The degrees of freedom for signal for trace gas vertical profiles retrieved in this study generally ranged from about 1 to 2 . Of the vertical profiles retrieved, concentration data in the $0-1 \mathrm{~km}$ layer were analyzed as PBL concentrations. This layer is the lowest layer in profiles retrieved by JM2 and has the highest sensitivity, because it has the longest light path. The validity of the retrieved data was discussed by Irie et al. (2011). For the $\mathrm{O}_{3}$ retrieval, additional validation was performed via a comparison with ozonesonde data, as described in the next section, because only a few other studies have conducted 
such a validation. For a single measurement, the total uncertainties, including random and systematic errors, were estimated to be $15 \%\left(\mathrm{NO}_{2}\right), 24 \%(\mathrm{HCHO}), 26 \%$ $\left(\mathrm{O}_{3}\right)$, and $18 \%\left(\mathrm{H}_{2} \mathrm{O}\right)$ (Irie et al. 2011). For the retrievals, the systematic error was estimated by additional retrievals that assumed aerosol retrieval uncertainties of $30 \%$ for $\mathrm{NO}_{2}$ and $\mathrm{H}_{2} \mathrm{O}$ and $50 \%$ for $\mathrm{HCHO}$ and $\mathrm{O}_{3}$ (Irie et al. 2008, 2011). The error estimate could be underestimated, because all the error sources have not been considered. From the retrieved $\mathrm{H}_{2} \mathrm{O}$ concentration, the relative humidity over water $\left(\mathrm{RH}_{\mathrm{w}}\right)$ for the $0-1 \mathrm{~km}$ layer was estimated using National Centers for Environmental Prediction pressure and temperature reanalysis data $(2.5$ degree grid and 6 hourly). For cloud screening, we only analyzed data with an $\mathrm{RH}_{\mathrm{w}}$ lower than $90 \%$. Cloud screening based on MAX-DOAS-derived $\mathrm{RH}_{\mathrm{w}}$ was shown to be effective in comparison with other independent data reported by Takashima et al. (2009). For a simple and consistent analysis across different seasons, the daily median values for 9:00-15:00 LT (local time) were calculated. More detailed descriptions of our MAX-DOAS system, including the instrumentation and algorithm, can be found in Irie et al. (2008, 2011, 2015, 2019) and the references therein.

\section{Results and discussion}

First, to evaluate our MAX-DOAS retrieval of $\mathrm{O}_{3}$, ozonesonde data obtained in the $0-1 \mathrm{~km}$ layer were analyzed as shown in Fig. 2. The data plotted here are from electrochemical concentration cell (ECC) ozonesondes, which were launched regularly from Tsukuba (Tateno) around 14:30 LT once per week. Also shown in Fig. 2 are mean $\mathrm{O}_{3}$ concentration data from 13:00-15:00 LT retrieved from MAX-DOAS observations at Chiba and
Tsukuba. These two sites are $\sim 50 \mathrm{~km}$ apart (Fig. 1). However, as shown in Fig. 2, both ozonesonde and MAX-DOAS data exhibited the same variations within the range of $\sim 20$ to $\sim 80 \mathrm{ppbv}$. Most of the data agreed well, particularly considering the total uncertainty in MAX-DOAS data of 26\% (Irie et al. 2011) and the temporal variation (and spatial variability for Chiba) in a day (13:00-15:00), as represented by the error bars in Fig. 2 . The MAX-DOAS data followed the daily and seasonal variations in ozonesonde data. Their correlation is shown in Fig. 3. The linear least-squares fit shows a moderate correlation, with a correlation coefficient $(R)$ of 0.63 . The $R$ value for the comparison with Tsukuba MAX-DOAS (0.69) was better than that with Chiba MAX-DOAS (0.62), presumably due to the fact that MAX-DOAS and ozonesonde observations were made relatively nearby for Tsukuba. The slope indicates the underestimation tendency in MAX-DOAS $\mathrm{O}_{3}$ data. This was likely insignificant due to the relatively large total uncertainty in MAX-DOAS $\mathrm{O}_{3}$ data. The mean $\mathrm{O}_{3}$ concentration $( \pm 1 \sigma$ standard deviation) from MAX-DOAS was $53 \pm 14 \mathrm{ppbv}$, whereas that from ozonesondes was $61 \pm 13$ ppbv. Thus, the validity of our MAX-DOAS observations and retrievals was well supported via comparison with ozonesonde data.

Figure 4 shows the seasonal variations in the $\mathrm{NO}_{2}$ and $\mathrm{HCHO}$ concentrations, $\mathrm{HCHO} / \mathrm{NO}_{2}$ concentration ratio, and $\mathrm{O}_{3}$ concentration in the lowest layer (altitude of $0-1$ $\mathrm{km})$ retrieved from MAX-DOAS observations at Chiba and Tsukuba, Japan for the 2013-2019 period. As expected, $\mathrm{NO}_{2}$ concentrations were higher in winter than in other seasons for both Chiba and Tsukuba. This was mainly because the lifetime of $\mathrm{NOx}$ is longer and the $\mathrm{NO} / \mathrm{NO}_{2}$ concentration ratio is lower in winter due to

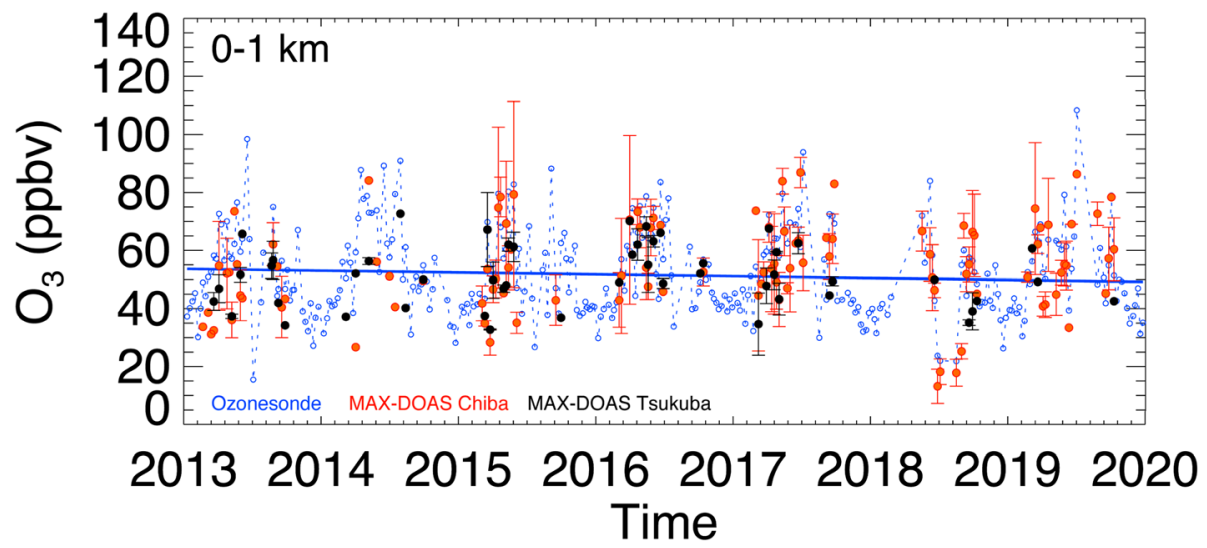

Fig. 2 Time series of $\mathrm{O}_{3}$ concentrations for the $0-1 \mathrm{~km}$ layer measured by ozonesondes launched at Tsukuba (Tateno), Japan (blue). The ozonesonde was launched around 14:30 LT once per week. The linear trend is shown by the blue line. Mean $\mathrm{O}_{3}$ concentrations for 13:00-15:00 LT retrieved from MAX-DOAS observations at Chiba and Tsukuba are shown daily in red and black, respectively. For clarity, MAX-DOAS data are shown only for the days when ozonesonde data were available. Error bars represent standard deviations within 13:00-15:00 LT (plus spatial variabilities in four different azimuth directions for Chiba) 


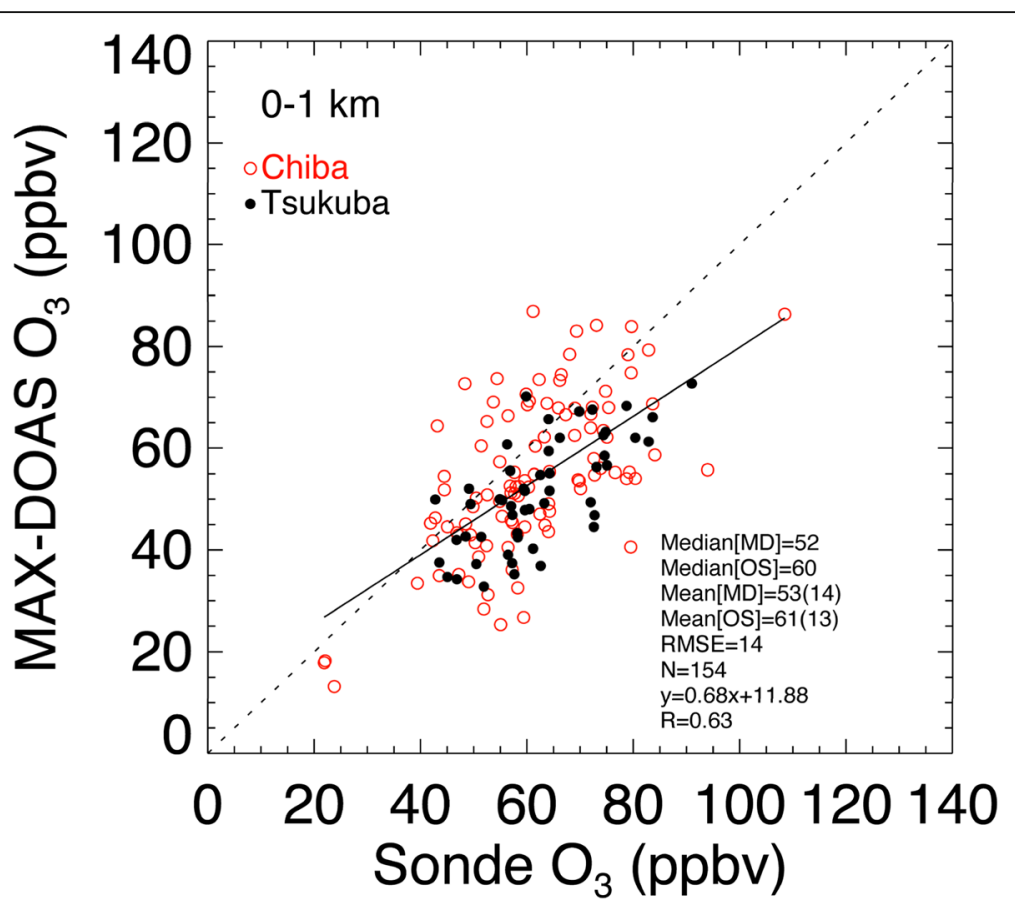

Fig. 3 Correlations between the ozonesonde and MAX-DOAS $\mathrm{O}_{3}$ concentration data shown in Fig. 2. Their medians, means, and 1- $\sigma$ standard deviations (in brackets after the means) are given. The root-mean-square error, number of comparisons, and equation of the linear least-squares fitting, and correlation coefficient are given. The linear least-squares fitting and 1:1 lines are shown by solid and dashed lines, respectively

less photochemical activity. Annual mean $\mathrm{NO}_{2}$ concentrations for the $0-1 \mathrm{~km}$ layer were estimated to be 4.1 and 1.9 ppbv for Chiba and Tsukuba, respectively (Table 1), reflecting the fact that Chiba is located close to strong emission sources in the Tokyo Bay area (Fig. 1). Annual mean $\mathrm{HCHO}$ concentrations for the $0-1 \mathrm{~km}$ layer were 1.7 and $2.2 \mathrm{ppbv}$ for Chiba and Tsukuba, respectively (Table 1). The $\mathrm{HCHO}$ concentrations were higher than $1.0 \mathrm{ppbv}$ in all months (Fig. 4), whereas the surface level of $\mathrm{HCHO}$ in the remote marine atmosphere was reported to be below $1.0 \mathrm{ppbv}$ (Weller et al. 2000; Singh et al. 2004). The HCHO data exhibited clear summer peaks at both sites, due to the significant secondary production of $\mathrm{HCHO}$ by summertime photochemical activity compared to other seasons. In addition, more $\mathrm{HCHO}$ was likely produced from the oxidation of biogenic VOCs (BVOCs), such as isoprene, whose emissions increase as the ambient temperature rises. The larger $\mathrm{HCHO}$ concentrations at Tsukuba were likely a result of more BVOC emissions around Tsukuba (Chatani et al. 2015, 2018). The retrieved $\mathrm{O}_{3}$ concentrations were similar for Chiba and Tsukuba, except for July and August. A southerly wind usually dominates in those months (e.g., Tanimoto et al. 2005; Kiriyama et al. 2015) as the North Pacific High extends northwestward around Japan, bringing clean maritime air masses into the Tokyo Bay area, including Chiba. The air masses then pass over the Tokyo Bay area to reach Tsukuba, which is located approximately $50 \mathrm{~km}$ downwind of
Chiba. During the transport, strong photochemistry in summer leads to significant secondary production of $\mathrm{O}_{3}$, resulting in a greater concentration of $\mathrm{O}_{3}$ in Tsukuba. Thus, seasonal variations in the $\mathrm{NO}_{2}, \mathrm{HCHO}$, and $\mathrm{O}_{3}$ concentrations retrieved from MAX-DOAS observations were considered reasonable. In response to the seasonal variations in $\mathrm{NO}_{2}$ and $\mathrm{HCHO}$ concentrations, the $\mathrm{HCHO} / \mathrm{NO}_{2}$ concentration ratio also displayed significant seasonality, with a large ratio in summer compared to the other seasons (Fig. 4).

Surface concentrations were measured regularly by the Atmospheric Environmental Regional Observation System (AEROS or Soramamekun in Japanese) at seven and four stations in the vicinity of our observation sites in Chiba and Tsukuba, respectively. For $\mathrm{O}_{x}$, the surface concentration around both sites for March-October, when MAX-DOAS $\mathrm{O}_{3}$ monthly data were available, was $\sim 35$ ppbv (annual average in daytime), which was lower than the mean $\mathrm{O}_{3}$ concentration at $0-1 \mathrm{~km}$ retrieved from MAX-DOAS ( 48 ppbv). This difference reflects the typical vertical profile shape of $\mathrm{O}_{3}$ in the PBL because the MAX-DOAS $\mathrm{O}_{3}$ data showed a reasonable agreement with the ozonesonde data (Figs. 2 and 3). Some of the difference could be caused by the fact that the MAX-DOAS instruments were on the rooftop of one of the tallest buildings (at $\sim 30 \mathrm{~m}$ from the surface) in Chiba University. Similarly, according to the typical vertical profile shape of $\mathrm{NO}_{2}$ in the $\mathrm{PBL}$, surface 

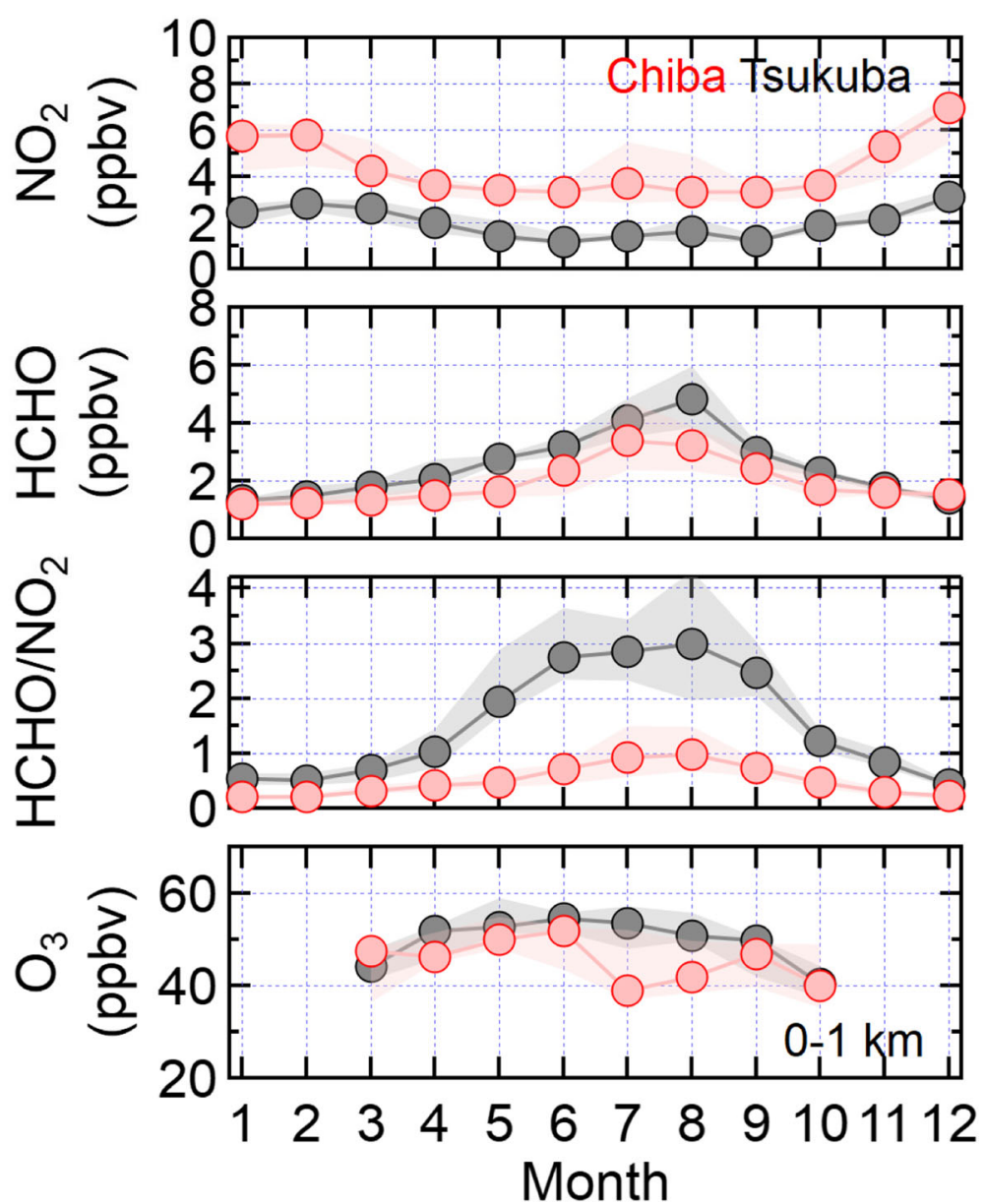

Fig. 4 Seasonal variations in $\mathrm{NO}_{2}$ and $\mathrm{HCHO}$ concentrations, $\mathrm{HCHO} / \mathrm{NO}_{2}$ concentration ratio, and $\mathrm{O}_{3}$ concentration for the lowest layer (altitude of 0-1 km) retrieved from MAX-DOAS observations at Chiba (red) and Tsukuba (black), Japan for 2013-2019. The O3 data for January, February, November, and December were unavailable, because the amount of retrieved data at $\mathrm{SZA}<50^{\circ}$ with less influence by high-altitude $\mathrm{O}_{3}$ was limited (see the text for more details). The median values of monthly means for the 7 years are shown. Shaded areas represent $67 \%$ ranges

Table. 1. Means, medians, and change rates for $\mathrm{NO}_{2}, \mathrm{HCHO}$, and $\mathrm{O}_{3}$ concentrations in the lowest layer (altitude of $0-1 \mathrm{~km}$ ) retrieved from MAX-DOAS observations at Chiba and Tsukuba, Japan, for 2013-2019. The change rates and determination coefficient $\left(R^{2}\right)$ were calculated by a linear least-squares fit. Statistics for the 8 months of March to October, when MAX-DOAS $\mathrm{O}_{3}$ data were available, are given. For $\mathrm{NO}_{2}$ and $\mathrm{HCHO}$, statistics for 12 months are also given in brackets

\begin{tabular}{|c|c|c|c|c|c|c|}
\hline Species & Location & Mean (ppbv) & Median (ppbv) & Change rate (ppbv/year) & Change rate (\%/year) & $R^{2}$ \\
\hline \multirow[t]{2}{*}{$\mathrm{NO}_{2}$} & Chiba & $\begin{array}{l}3.6 \\
(4.1)\end{array}$ & $\begin{array}{l}3.6 \\
(4.1)\end{array}$ & $\begin{array}{l}-0.2 \\
(-0.3)\end{array}$ & $\begin{array}{l}-6 \\
(-7)\end{array}$ & $\begin{array}{l}0.50 \\
(0.76)\end{array}$ \\
\hline & Tsukuba & $\begin{array}{l}1.6 \\
(1.9)\end{array}$ & $\begin{array}{l}1.5 \\
(1.9)\end{array}$ & $\begin{array}{l}-0.1 \\
(-0.1)\end{array}$ & $\begin{array}{l}-6 \\
(-5)\end{array}$ & $\begin{array}{l}0.48 \\
(0.65)\end{array}$ \\
\hline \multirow[t]{2}{*}{$\mathrm{HCHO}$} & Chiba & $\begin{array}{l}2.0 \\
(1.7)\end{array}$ & $\begin{array}{l}2.2 \\
(1.7)\end{array}$ & $\begin{array}{l}-0.2 \\
(-0.1)\end{array}$ & $\begin{array}{l}-10 \\
(-6)\end{array}$ & $\begin{array}{l}0.83 \\
(0.67)\end{array}$ \\
\hline & Tsukuba & $\begin{array}{l}2.8 \\
(2.2)\end{array}$ & $\begin{array}{l}2.8 \\
(2.1)\end{array}$ & $\begin{array}{l} \pm 0.0 \\
( \pm 0.0)\end{array}$ & $\begin{array}{l} \pm 0 \\
( \pm 0)\end{array}$ & $\begin{array}{l}0.17 \\
(0.03)\end{array}$ \\
\hline \multirow[t]{2}{*}{$\mathrm{O}_{3}$} & Chiba & 47 & 47 & +0.5 & +1 & 0.28 \\
\hline & Tsukuba & 49 & 50 & -0.1 & \pm 0 & 0.37 \\
\hline
\end{tabular}


concentrations of $\mathrm{NO}_{2}(\sim 14$ and $\sim 9$ ppbv at Chiba and Tsukuba, respectively) were higher than MAX-DOAS data for the $0-1 \mathrm{~km}$ layer. Surface concentration data for $\mathrm{HCHO}$ were unavailable but non-methane hydrocarbon (NMHC) concentrations were $\sim 106$ and $\sim 92 \mathrm{ppbC}$ around Chiba and Tsukuba, respectively, with the greater anthropogenic NMHC emissions likely contributing to the higher NMHC concentration around Chiba compared to Tsukuba.

Figure 5 shows the year-to-year variations in the $\mathrm{NO}_{2}$ and $\mathrm{HCHO}$ concentrations, $\mathrm{HCHO} / \mathrm{NO}_{2}$ concentration ratio, and $\mathrm{O}_{3}$ concentration for the $0-1 \mathrm{~km}$ layer retrieved from MAX-DOAS observations at Chiba and Tsukuba. The median values for the 8-month period (March to October) are plotted for each year. Because Chiba and Tsukuba are located in an urban and suburban area, respectively, the $\mathrm{NO}_{2}$ concentration was higher in Chiba but the rate of decrease was similar for both Chiba and Tsukuba (6-7\%/year) (Table 1). For HCHO, the 8- and 12-month median concentrations for Tsukuba were 2.8 and $2.2 \mathrm{ppbv}$, respectively. These values were higher than those at Chiba (2.0 and 1.7 ppbv) because more significant BVOC emissions likely occurred around Tsukuba (Chatani et al. 2015, 2018). It is interesting to note that an apparent decreasing trend in the $\mathrm{HCHO}$ concentration was observed at Chiba (6-10\%/ year) (Fig. 5 and Table 1). This was likely because emission control measures against anthropogenic VOCs, including primary emissions of $\mathrm{HCHO}$, have worked well (e.g., Akimoto 2017).

However, MAX-DOAS $\mathrm{O}_{3}$ data displayed almostconstant variations, particularly at Chiba (Fig. 5 and Table 1). The trend indicated by MAX-DOAS $\mathrm{O}_{3}$ data for Tsukuba was found to be very similar to that from ozonesonde observations (Fig. 2). For Chiba, there were clear reductions in both $\mathrm{NO}_{2}$ and $\mathrm{HCHO}$, and therefore, the in situ photochemical production of $\mathrm{O}_{3}$ must have decreased. The decrease should have been compensated
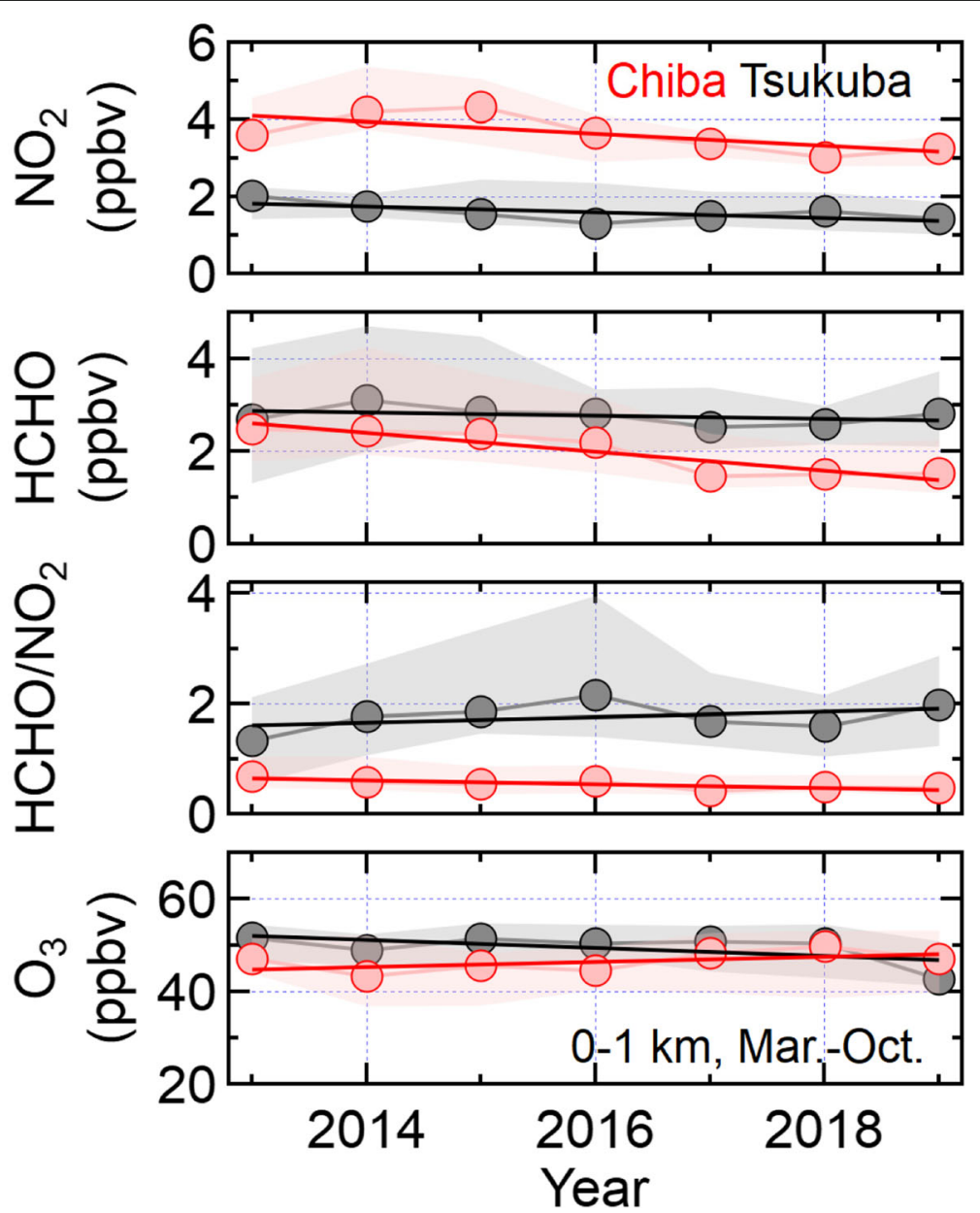

Fig. 5 Timeseries of $\mathrm{NO}_{2}$ and $\mathrm{HCHO}$ concentrations, $\mathrm{HCHO} / \mathrm{NO}_{2}$ concentration ratio, and $\mathrm{O}_{3}$ concentration for the lowest layer (altitude of $0-1$ km) retrieved from MAX-DOAS observations at Chiba (red) and Tsukuba, Japan. The median values for the 8 months (March to October), when MAX-DOAS $\mathrm{O}_{3}$ data were available, are shown for each year. Shaded areas represent $67 \%$ ranges 
for by the impact of the decrease in the NO titration effect and/or increase in the transboundary-transported $\mathrm{O}_{3}$ from the Asian continent. Investigations of these effects have largely been conducted through model simulations using the emission inventories, which became available several years later (Akimoto 2017 and references therein). However, the present study emphasizes the importance of the NO titration effect, from our observations only that were conducted over a unique time period, as shown by satellite observations reported below.

As done by Irie et al. (2016), the tropospheric $\mathrm{NO}_{2}$ burdens $(B)$ over the entire area of China, Japan, and South Korea were estimated by multiplying the annual averages of tropospheric $\mathrm{NO}_{2}$ vertical column density (VCD) from Ozone Monitoring Instrument (OMI) observations (Levelt et al. 2006) over the respective areas of each country, as follows:

$$
B=V M S / A
$$

where $V$ is the annual average of the tropospheric $\mathrm{NO}_{2} \mathrm{VCD}$ values over the entire area of the respective countries, $M$ is the molecular weight of $\mathrm{NO}_{2}, S$ is the national area, and $A$ is Avogadro's number. For this estimate, the OMI data from the Quality Assurance for Essential Climate Variable project (Boersma et al. 2018) were used. A country code map created from national boundary data (http://hydro.iis.u-tokyo.ac.jp/GW/ basemap/) was used to assess the OMI data corresponding to each country. To minimize the possible effects of row anomalies in OMI observations and cloud and snow/ice coverage on estimates of national-mean VCDs, the OMI data were first averaged over a $1^{\circ} \times 1^{\circ}$ grid for each month, and then the gridded values were averaged over the entire national area.

In Japan, it was found that the tropospheric $\mathrm{NO}_{2}$ burden declined by approximately half from 2005 to 2019 (Fig. 6). In South Korea, no significant trend was apparent, but the $\mathrm{NO}_{2}$ concentration decreased overall by $\sim 10 \%$ from 2005 to 2019. In China, the estimated $\mathrm{NO}_{2}$ burden decreased at a rate of $\sim 10 \%$ /year from 2013 to 2016, which was significant compared to other periods (Fig. 6). Variations in the $\mathrm{NO}_{2}$ burden were almost constant in the 3-year periods before and after 2014-2015 (i.e., 2011-2013 and 2016-2018). The mean $\mathrm{NO}_{2}$ burden in 2016-2018 corresponded to $74 \%$ of that in 20112013 , representing a $26 \%$ reduction between the two

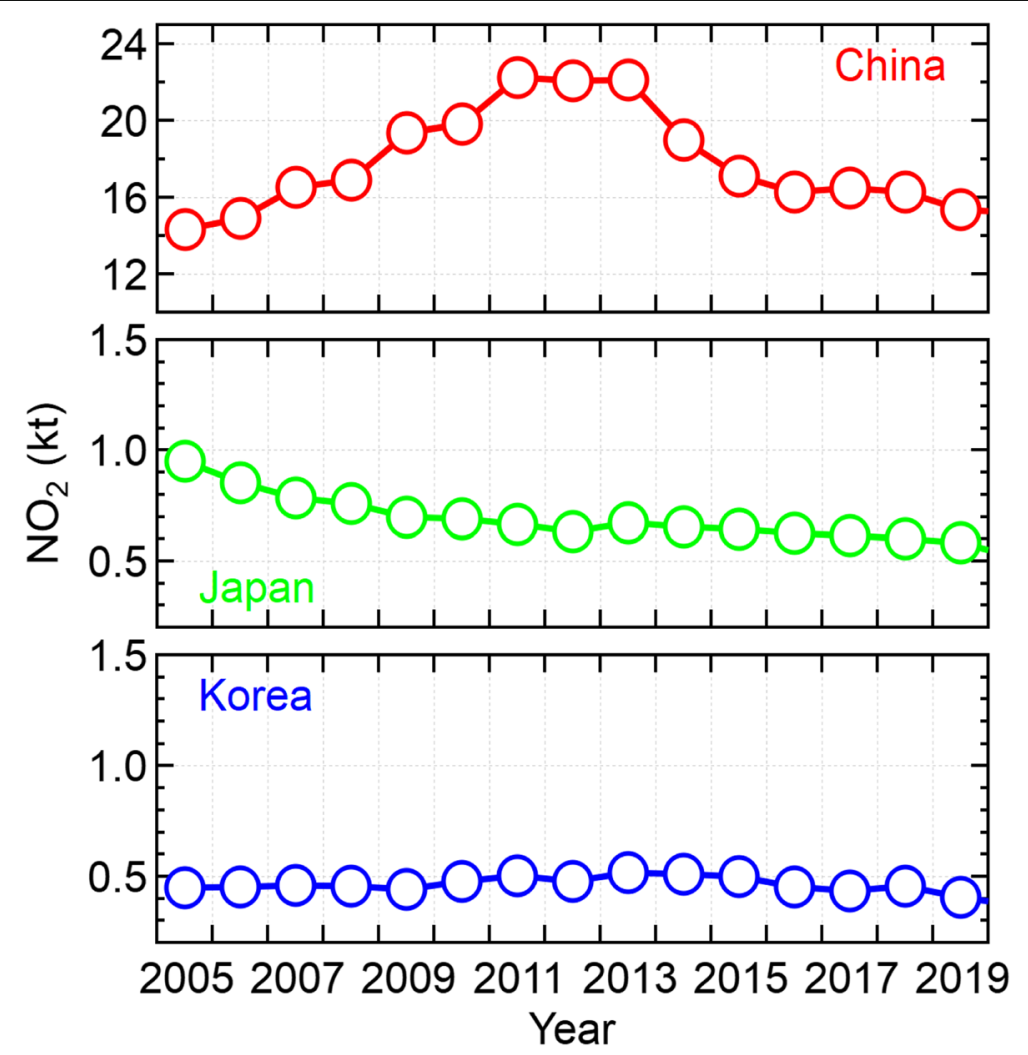

Fig. 6 Updated results of a trend analysis using OMI tropospheric $\mathrm{NO}_{2}$ VCD data by Irie et al. (2016). Temporal variations in annual mean tropospheric $\mathrm{NO}_{2}$ burdens over the entire national area of China (red), Japan (green), and South Korea (blue) are shown. The burdens were estimated by multiplying the annual averages of OMI tropospheric $\mathrm{NO}_{2} \mathrm{VCD}$ data over the entire national area by the area of each country 
periods. Summing up the data for China, Japan, and South Korea confirmed that tropospheric $\mathrm{NO}_{2}$ levels over East Asia have improved substantially in recent years.

Li et al. (2019) analyzed observation data in China and estimated that anthropogenic NOx emissions decreased by $21 \%$ from 2013 to 2017 and VOC emissions changed little. Consistent estimates were made by Zheng et al. (2018) using a combination of a bottom-up emission inventory and index decomposition analysis approaches. A slight increasing trend in $\mathrm{O}_{3}$ of 1-3 ppbv/year was observed only in megacity clusters in eastern China. Shen et al. (2019) showed that an insignificant change in $\mathrm{HCHO}$, at a rate of $1 \% /$ year, occurred from 2011 to 2016 in China. There were consistent tendencies seen in these trace gas concentrations, but smaller rates of changes in $\mathrm{O}_{3}$ were suggested from model simulations by Liu and Wang (2020a, b). Assuming that such variations in $\mathrm{NO}_{2}$ and $\mathrm{HCHO}$ continued until 2019, the amount of $\mathrm{O}_{3}$ transported as transboundary air pollution from the Asian continent is likely to have been suppressed or remained unchanged over the period of the present study. Furthermore, a sensitivity analysis using regional chemical transport models (Chatani et al. 2020) suggested that the impact of transboundary transport on $\mathrm{O}_{3}$ in the Kanto area, which was the location of our observation sites (Chiba and Tsukuba), was much smaller than that of local photochemistry.

Therefore, it is likely that for our observations at Chiba, the decrease in in situ photochemical production of $\mathrm{O}_{3}$ was compensated for by the impact of the decrease in the NO titration effect. Thus, NO titration played a critical role in determining $\mathrm{O}_{3}$ concentrations. The decreasing NOx concentration significantly reduced the amount of $\mathrm{O}_{3}$ quenched through $\mathrm{NO}$ titration. This effect would have been more significant in Chiba than in Tsukuba, because more fresh $\mathrm{NO}$ is available around Chiba, which is closer to strong NOx emission sources. This observational evidence, without any model simulations or emission inventories, indicated that the dominant $\mathrm{O}_{3}$ production regime around Chiba was the VOClimited regime.

To demonstrate the suitability of continuous multicomponent MAX-DOAS observations in the analysis of variations in PBL $\mathrm{O}_{3}$, correlations between $\mathrm{HCHO}$ and $\mathrm{NO}_{2}$ concentrations retrieved by MAX-DOAS for the $0-1 \mathrm{~km}$ layer were plotted (Fig. 7). To use the largest amount of $\mathrm{HCHO}$ and $\mathrm{NO}_{2}$ data, an analysis was first conducted using 12-month data. The results showed that the $\mathrm{HCHO} / \mathrm{NO}_{2}$ concentration ratio for Chiba was below unity and almost unchanged at around 0.4-0.5 from 2013 to 2019 because the $\mathrm{NO}_{2}$ and $\mathrm{HCHO}$ concentrations decreased at a similar rate (Table 1). From similar analyses using data collected over 8 months (March to October), when $\mathrm{O}_{3}$ data were also available, and using data collected in the three summer months (June to August), which are the most critical for in situ $\mathrm{O}_{3}$ photochemistry, it was found that the $\mathrm{HCHO} / \mathrm{NO}_{2}$ concentration ratio was below unity, while the $\mathrm{HCHO} /$ $\mathrm{NO}_{2}$ concentration ratio tended to be large in the three summer months compared to the 8- and 12-month analyses. This was further confirmed by the data on seasonal variations, which showed that the $\mathrm{HCHO} / \mathrm{NO}_{2}$ concentration ratio was below unity in all months. Our finding that the MAX-DOAS-derived $\mathrm{HCHO} / \mathrm{NO}_{2}$ concentration ratio was below unity under VOC-limited conditions was consistent with those of previous studies using model simulations, satellite observations, and in

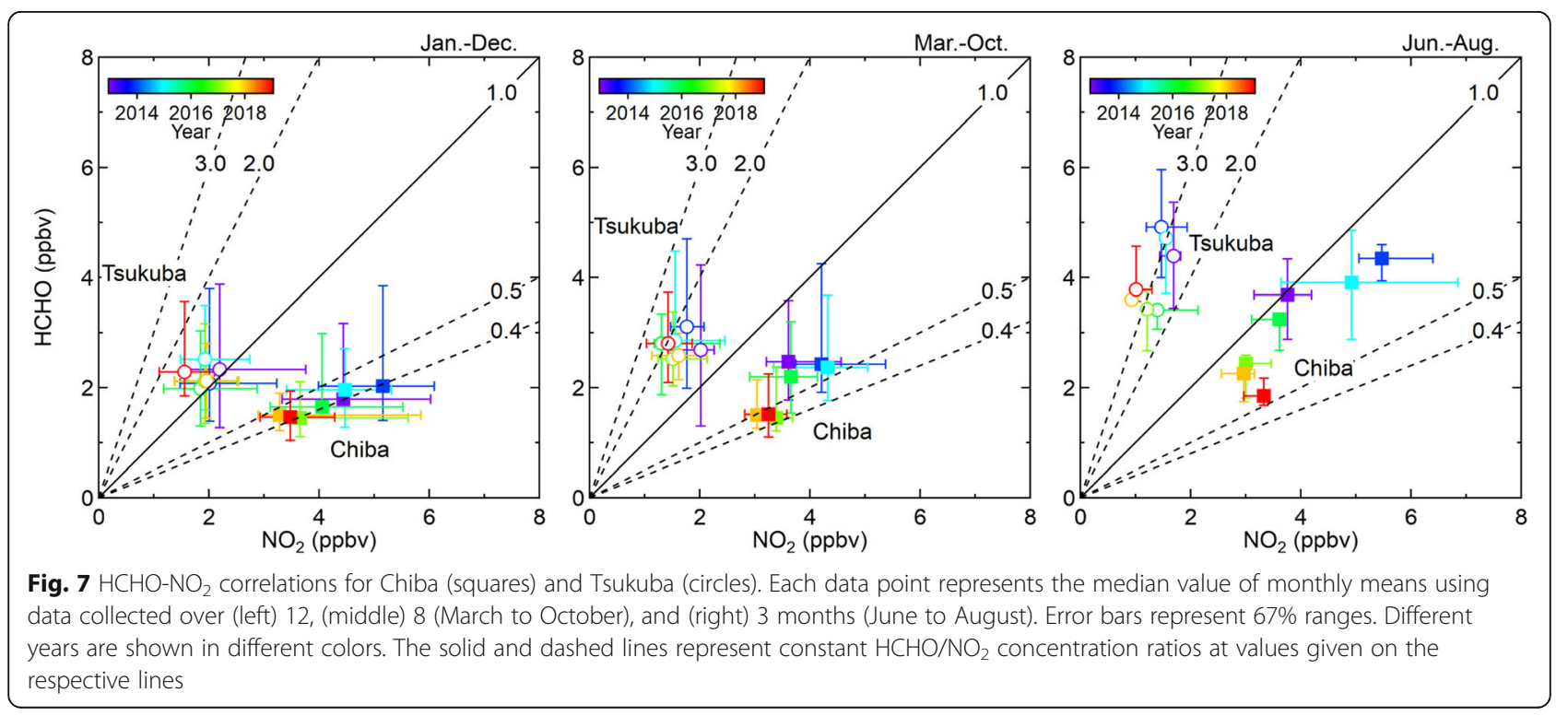


situ aircraft observations (e.g., Tonnesen and Dennis 2000; Martin et al. 2004; Duncan et al. 2010; Schroeder et al. 2017). Because we focused on the PBL (i.e., the 0$1 \mathrm{~km}$ layer), it was expected that the multi-component observations from MAX-DOAS would provide a unique $\mathrm{O}_{3}, \mathrm{NO}_{2}$, and $\mathrm{HCHO}$ data set for analyzing $\mathrm{O}_{3}$ variations in the PBL (neither column nor surface concentrations).

It was interesting to further note a decreasing tendency in the $\mathrm{HCHO} / \mathrm{NO}_{2}$ concentration ratio at Chiba from 2013 to 2019 (Figs. 5 and 7), suggesting that the dominant $\mathrm{O}_{3}$ production regime shifted to a more VOClimited regime. During the same period, an increase in the $\mathrm{HCHO} / \mathrm{NO}_{2}$ ratio was suggested to have occurred but the value was still below $\sim 3$ (as a summertime peak value) for Tsukuba (Figs. 4, 5, and 7). Although our analysis of $\mathrm{O}_{3}$ data revealed an insignificant change in the annual trend in $\mathrm{O}_{3}$ concentration at Tsukuba (Figs. 2 and 5), further continuous multi-component MAXDOAS observations for both Chiba and Tsukuba are encouraged to investigate $\mathrm{O}_{3}$ sensitivity, which may remain unchanged or range within a NOx-limited, VOC-limited, or their transition/ambiguous region in the near future.

\section{Conclusions}

We used the MAX-DOAS technique to conduct continuous simultaneous observations of $1 \mathrm{~km}$ thick PBL (at an altitude of $0-1 \mathrm{~km}) \mathrm{O}_{3}, \mathrm{NO}_{2}$, and $\mathrm{HCHO}$ concentrations at Chiba and Tsukuba, Japan, for 7 years from 2013 to 2019. In the 7-year period, satellite observations by the OMI indicated an abrupt decrease in the tropospheric $\mathrm{NO}_{2}$ concentration over East Asia, including China, suggesting that the transboundary transport of $\mathrm{O}_{3}$ originating from the Asian continent was likely suppressed or remained unchanged. Over the same time period, MAX-DOAS observations showed almostconstant variations in the $\mathrm{PBL} \mathrm{O}_{3}$ concentration at Chiba, whereas reductions in the $\mathrm{NO}_{2}$ and $\mathrm{HCHO}$ concentrations occurred at rates of approximately $6-10 \% /$ year at Chiba. These results provide clear observational evidence that the decreasing NOx concentration significantly reduced the amount of $\mathrm{O}_{3}$ quenched through $\mathrm{NO}$ titration under VOC-limited conditions at Chiba, which is situated in an urban area. The MAX-DOAS-derived $\mathrm{HCHO} / \mathrm{NO}_{2}$ concentration ratio had a value below unity for all months. Thus, the multi-component observations from MAX-DOAS provided a unique data set of $\mathrm{O}_{3}$, $\mathrm{NO}_{2}$, and $\mathrm{HCHO}$ concentrations for analyzing variations in PBL $\mathrm{O}_{3}$. The data set is expected to be useful for developing a better understanding of the processes leading to $\mathrm{PBL} \mathrm{O}_{3}$ variation.

\section{Abbreviations}

MAX-DOAS: Multi-axis differential optical absorption spectroscopy; DOAS: Differential optical absorption spectroscopy; VOCs: Volatile organic compounds; SLCFs: Short-lived climate forcers; SLCPs: Short-lived climate pollutants; CINDI: Cabauw intercomparison campaign of nitrogen dioxide measuring Instruments; JM2: Japanese MAX-DOAS profile retrieval algorithm, version 2; PBL: Planetary boundary layer; SZA: Solar zenith angle; RHw: Relative humidity over water; NCEP: National centers for environmental prediction; LT: Local time; BVOCs: Biogenic volatile organic compounds; AEROS: Atmospheric environmental regional observation system; NMHC: Non-methane hydrocarbon; VCD: Vertical column density; OMI: Ozone monitoring instrument

\section{Acknowledgements}

The MAX-DOAS observations at Tsukuba were supported by T. Nagai of Meteorological Research Institute. We acknowledge the free use of tropospheric $\mathrm{NO}_{2}$ column data from the OMl sensor from www.temis.nl and the free use of ozonesonde data from World Ozone and UV Data Center. This research was supported by the Environment Research and Technology Development Fund (JPMEERF20192001 and JPMEERF20215005) of the Environmental Restoration and Conservation Agency of Japan, JSPS KAKENHI (grant numbers JP19H04235 and JP2OH04320), and the JAXA 2nd research announcement on the Earth Observations (grant number 19RT000351).

\section{Authors' contributions}

$H I, D Y$, and AD designed the present study, performed observation and analysis, and wrote the paper, with support from all the authors. HMSD, KS, and SI gave useful comments. The authors read and approved the final manuscript.

\section{Funding}

This research was supported by the Environment Research and Technology Development Fund (JPMEERF20192001 and JPMEERF20215005) of the Environmental Restoration and Conservation Agency of Japan, JSPS KAKENHI (grant numbers JP19H04235 and JP2OH04320), and the JAXA 2nd research announcement on the Earth Observations (grant number 19RT000351).

\section{Availability of data and materials}

The data are available upon request to the corresponding author (hitoshi. irie@chiba-u.jp).

\section{Declarations}

\section{Competing interests}

The authors declare that they have no competing interests.

\section{Author details}

${ }^{1}$ Center for Environmental Remote Sensing, Chiba University, 1-33 Yayoicho, Inage-ku, Chiba 263-8522, Japan. ${ }^{2}$ Graduate School of Environmental Studies, Nagoya University, Furocho, Chigusa-ku, Nagoya 464-8601, Japan.

${ }^{3}$ Environmental Science Research Laboratory, Central Research Institute of Electric Power Industry, Abiko 270-1194, Japan.

Received: 20 December 2020 Accepted: 12 April 2021

Published online: 06 May 2021

\section{References}

Akimoto H (2017) Overview of policy actions and observational data for PM2.5 and $\mathrm{O} 3$ in Japan: a study of urban air quality improvement in Asia, JICA-RI Working Paper, 137

Boersma KF, Eskes H, Richter A, De Smedt I, Lorente A, Beirle S, Zara M, Peters E, Roozendael MV, Wagner T, Maasakkers JD, van Der ARJ, Nightingale J, De Rudder A, Irie H, Pinardi G, Lambert J-C, and Compernolle S (2018) Improving algorithms and uncertainty estimates for satellite $\mathrm{NO}_{2}$ retrievals: Results from the Quality Assurance for Essential Climate Variables (QA4ECV) project, Atmos Meas Tech, 11, 6651-6678, https://doi.org/https://doi.org/10.5194/amt-11$6651-2018,12$

Chatani S, Matsunaga S, Nakastuka S (2015) Estimate of biogenic VOC emissions in Japan and their effects on photochemical formation of ambient ozone and secondary organic aerosol. Atmos Environ 120:38-50. https://doi.org/10.1 016/j.atmosenv.2015.08.086

Chatani S, Okumura M, Shimadera H, Yamaji K, Kitayama K, Matsunaga SN (2018) Effects of a detailed vegetation database on simulated meteorological fields, biogenic VOC emissions, and ambient pollution concentrations over Japan. Atmosphere 9(5):179. https://doi.org/10.3390/atmos9050179 
Chatani S, Shimadera H, Itahashi S, and Yamaji K (2020) Comprehensive analyses of source sensitivities to and apportionments of $\mathrm{PM}_{2.5}$ and ozone over Japan via multiple numerical techniques, Atmos Chem Phys Discuss., https://doi. org/https://doi.org/10.5194/acp-2020-236

Duncan BN, Yoshida Y, Olson JR, Sillman S, Martin RV, Lamsal L, Hu Y, Pickering KE, Retscher C, Allen DJ, Crawford JH (2010) Application of OMI observations to a space-based indicator of NOx and VOC controls on surface ozone formation. Atmos Environ 44(18):2213-2223. https://doi.org/10.1016/j.a tmosenv.2010.03.010

Hönninger G, Platt U (2002) Observations of $\mathrm{BrO}$ and its vertical distribution during surface ozone depletion at Alert. Atmos Environ 36(15-16):2481-2489. https://doi.org/10.1016/S1352-2310(02)00104-8

Hönninger G, von Friedeburg C, Platt U (2004) Multi axis differential optical absorption spectroscopy (MAX-DOAS). Atmos. Chem. Phys. 4(1):231-254. https://doi.org/10.5194/acp-4-231-2004

Irie H, Hoque HMS, Damiani A, Okamoto H, Fatmi AM, Khatri P, Takamura T, Jarupongsakul T (2019) Simultaneous observations by sky radiometer and MAX-DOAS for characterization of biomass burning plumes in central Thailand in January-April 2016. Atmos Meas Tech 12(1):599-606. https://doi. org/10.5194/amt-12-599-2019

Irie $H$, Kanaya Y, Akimoto H, Iwabuchi H, Shimizu A, Aoki K (2008) First retrieval of tropospheric aerosol profiles using MAX-DOAS and comparison with lidar and sky radiometer measurements. Atmos Chem Phys 8(2):341-350. https:// doi.org/10.5194/acp-8-341-2008

Irie H, Muto T, Itahashi S, Kurokawa J, Uno I (2016) Turnaround of tropospheric nitrogen dioxide pollution trends in China, Japan, and South Korea. Sci Online Lett Atmos 12(0):170-174. https://doi.org/10.2151/sola.2016-035

Irie H, Nakayama T, Shimizu A, Yamazaki A, Nagai T, Uchiyama A, Zaizen Y, Kagamitani S, Matsumi Y (2015) Evaluation of MAX-DOAS aerosol retrievals by coincident observations using CRDS, lidar, and sky radiometer in Tsukuba, Japan. Atmos Meas Tech 8(7):2775-2788. https://doi.org/10.5194/amt-8-2 775-2015

Irie H, Takashima H, Kanaya Y, Boersma KF, Gast L, Wittrock F, Brunner D, Zhou Y, Van Roozendael M (2011) Eight-component retrievals from ground-based MAX-DOAS observations. Atmos Meas Techn 4(6):1027-1044. https://doi. org/10.5194/amt-4-1027-2011

Kiriyama Y, Shimadera H, Itahashi S, Hayami H, Miura K (2015) Evaluation of the effect of regional pollutants and residual ozone on ozone concentrations in the morning in the inland of the Kanto region. Asian J Atmos Environ 9(1):111. https://doi.org/10.5572/ajae.2015.9.1.001

Kreher K, Van Roozendael M, Hendrick F, Apituley A, Dimitropoulou E, Frieß U, Richter A, Wagner T, Abuhassan N, Ang L, Anguas M, Bais A, Benavent N, Bösch T, Bognar K, Borovski A, Bruchkouski I, Cede A, Chan KL, Donner S, Drosoglou T, Fayt C, Finkenzeller H, Garcia-Nieto D, Gielen C, Gómez-Martín L, Hao N, Herman JR, Hermans C, Hoque S, et al. (2020) Intercomparison of $\mathrm{NO}_{2}, \mathrm{O}_{4}, \mathrm{O}_{3}$ and $\mathrm{HCHO}$ slant column measurements by MAX-DOAS and zenith-sky UV-Visible spectrometers during CINDI-2, Atmos Meas Tech, https://doi.org/https://doi.org/10.5194/amt-2019-157, accepted

Levelt PF, van den Oord GHJ, Dobber MR, Malkki A, Visser $H$, de Vries J, Stammes P, Lundell J, Saari H (2006) The ozone monitoring instrument. IEEE Trans. Geosci Remote Sens 44:1093-1101. https://doi.org/10.1109/TGRS.2006.872333

Li K, Jacob DJ, Liao H, Shen L, Zhang Q, and Bates KH (2019) Anthropogenic drivers of 2013-2017 trends in summer surface ozone in China, PNAS, 116, 2 www.pnas.org/cgi/doi/https://doi.org/10.1073/pnas.1812168116, 2, 427

Liu Y, and Wang T (2020a) Worsening urban ozone pollution in China from 2013 to 2017 - Part 1: The complex and varying roles of meteorology, Atmos Chem Phys, 20:6305-6321, https://doi.org/https://doi.org/10.5194/acp-20-63 05-2020, 11

Liu Y, and Wang T (2020b) Worsening urban ozone pollution in China from 2013 to 2017 - Part 2: The effects of emission changes and implications for multipollutant control, Atmos Chem Phys, 20:6323-6337, https://doi.org/https:// doi.org/10.5194/acp-20-6323-2020, 11

Martin R, Fiore A, Van Donkelaar A (2004) Space-based diagnosis of surface ozone sensitivity to anthropogenic emissions. Geophys Res Lett 31(6):L06120. https://doi.org/10.1029/2004GL019416

Platt U, and Stutz J (2008) Differential optical absorption spectroscopy, principles and applications, Springer, XV, 597 p. 272 illus., 29 in color, Physics of Earth and Space Environments, ISBN 978-3-540-21193-8

Roscoe HK, Van Roozendael M, Fayt C, du Piesanie A, Abuhassan N, Adams C, Akrami M, Cede A, Chong J, Clemer K, Friess U, Ojeda MG, Goutail F, Graves R, Griesfeller A, Grossmann K, Hemerijckx G, Hendrick F, Herman J, Hermans
C, Irie H, Kanaya Y, Kreher K, Johnston P, Leigh R, Merlaud A, Mount MG, Navarro M, Oetjen H, Pazmino A et al (2010) Intercomparison of slant column measurements of $\mathrm{NO}_{2}$ and $\mathrm{O}_{4}$ by MAX-DOAS and zenith sky UV and visible spectrometers. Atmos Meas Tech 3(6):1629-1646. https://doi.org/10.51 94/amt-3-1629-2010

Schroeder J, Crawford JH, Fried A, Walega, Weinheimer A, Wisthaler A, Müller M, Mikoviny T, Chen G, Shook M, Black DR, and Tonnesen GS (2017) New insights into the column $\mathrm{CH}_{2} \mathrm{O} / \mathrm{NO}_{2}$ ratio as an indicator of near-surface ozone sensitivity, J Geophys Res, 122, 16:8885-8907, https://doi.org/https:// doi.org/10.1002/2017JD026781

Shen L, Jacob DJ, Zhu L, Zhang Q, Zheng B, Sulprizio MP, Li K, De Smedt I, González Abad G, Cao H, Fu TM, Liao H (2019) The 2005-2016 trends of formaldehyde columns over China observed by satellites: increasing anthropogenic emissions of volatile organic compounds and decreasing agricultural fire emissions. Geophys Res Lett 46(8):4468-4475, https://doi. org/10.1029/2019gl082172

Singh HB, Salas $\sqcup$, Chatfield RB, Czech E, Fried A, Walega J, Evans M, Field BD, Jacob DJ, Blake D, Heikes B, Talbot R, Sachse G, Crawford JH, Avery MA, Sandholm S, Fuelberg H (2004) Analysis of the atmospheric distribution, sources, and sinks of oxygenated volatile organic chemicals based on measurements over the Pacific during TRACE-P. J Geophys Res 109:D15S07. https://doi.org/10.1029/2003JD003883

Takashima H, Irie H, Kanaya Y, Shimizu A, Aoki K, Akimoto H (2009) Atmospheric aerosol variations at Okinawa Island in Japan observed by MAX-DOAS using a new cloud screening method. J Geophys Res 114(D18):D18213. https://doi. org/10.1029/2009JD011939

Tanimoto H, Sawa Y, Matsueda H, Uno I, Ohara T, Yamaji K, Kurokawa J, Yonemura S (2005) Significant latitudinal gradient in the surface ozone spring maximum over East Asia. Geophys Res Lett 32(21):L21805. https://doi. org/10.1029/2005GL023514

Tonnesen GS, Dennis RL (2000) Analysis of radical propagation efficiency to assess ozone sensitivity to hydrocarbons and NOx 2. long-lived species as indicators of ozone concentration sensitivity. J Geophys Res 105(D7):92279241

Weller R, Schrems O, Boddenberg A, Gab S, Gautrois M (2000) Meridional distribution of hydroperoxides and formaldehyde in the marine boundary layer of the Atlantic $\left(48^{\circ} \mathrm{N}-35^{\circ} \mathrm{S}\right)$ measured during the Albatross campaign. J Geophys Res 105(14):401-14 412

Wittrock F, Oetjen H, Richter A, Fietkau S, Medeke T, Rozanov A, and Burrows JP (2004) MAX-DOAS measurements of atmospheric trace gases in Ny-Ålesund Radiative transfer studies and their application, Atmos Chem Phys, 4, 955966, https://doi.org/https://doi.org/10.5194/acp-4-955-2004, 4

Zheng B, Tong D, Li M, Liu F, Hong C, Geng G, Li H, Li X, Peng L, Qi J, Yan L, Zhang Y, Zhao H, Zheng Y, He K and Zhang Q (2018) Trends in China's anthropogenic emissions since 2010 as the consequence of clean air actions, Atmos Chem Phys, 18:14095-14111, https://doi.org/https://doi.org/10.5194/a cp-18-14095-2018, 19

\section{Publisher's Note}

Springer Nature remains neutral with regard to jurisdictional claims in published maps and institutional affiliations.

\section{Submit your manuscript to a SpringerOpen ${ }^{\circ}$ journal and benefit from:}

- Convenient online submission

- Rigorous peer review

- Open access: articles freely available online

- High visibility within the field

- Retaining the copyright to your article

Submit your next manuscript at $\boldsymbol{\nabla}$ springeropen.com 